\title{
Література
}

1. Шнайдер Ф. Судебно-медицинское значение смерти при нетипичном сексуальном поведении: асфиксиофилии, аутоэротизме / Шнайдер Ф., Пиголкин Ю. И., Эрлих Э., Дмитриева О. А. // Судебно-медицинская экспертиза. (Россия) - 2003. - №6. - С. 28.

2. Farkasova lannaccone S. Nahodna smrt' pri autoerotike / Farkasova lannaccone S., Popadak P, Sopcova D., Ginelliova A, Nerantzakis I, Popadakova J. // Folia Societatis Medicinae Legalis Slovacae. - 2017. - Vol. 7, N 2. P. 135-139/

3. Sergey Sheleg Autoerotic Asphyxiation: Forensic, Medical, and Social Aspects / Sergey Sheleg, Edwin Ehrlich // Tucson, AZ: Wheatmark, 2006. - 208 p.

\section{AUTOEROTICA DEATH AS A RESULT OF COMPRESSION ASPHYXIA IN COMBINATION WITH STRANGULATE}

\author{
Danyluk M. V., Zozulya V. M., Chuiko A. V., Ghanaian E. V., Lesyk V.
}

Resume. Autoasia (erotic asphyxia) - a form of abnormal sexual activity related to the use of funds, limiting the access of oxygen to the lungs and to the brain to enhance sensations associated with sexual discharge. Is a quite dangerous practice because it may lead to unconsciousness and immobilization of a person. As a rule, Assil hides his occupation from others, even from the closest people, so the presence of this deviation becomes known only in the cases when such activity leads to death. Below is an example of autoerotic death by compressive asphyxia combined with strangulate.

Keywords: autoerotic asphyxiation.

\section{ВИВЧЕННЯ ВПЛИВУ ЕТИЛОВОГО СПИРТУ НА ТОЧНІСТЬ ВИЗНАЧЕННЯ ДАВНОСТІ НАСТАННЯ СМЕРТІ ЗА ДАНИМИ ЛАЗЕРНОЇ ПОЛЯРИМЕТРІЇ ПОЛІКРИСТАЛІЧНИХ ПЛІВОК ЦЕРЕБРОСПІНАЛЬНОЇ РІДИНИ}

\author{
() Гараздюк М.С. ${ }^{1}$, Бачинський В.Т. ${ }^{1}$, Лебедінцева I.O. ${ }^{3}$, \\ Гараздюк О.I. ${ }^{2}$, Андрійчук А.O ${ }^{3}$.
}

\begin{abstract}
Вищий державний навчальний заклад України «Буковинський державний медичний університет», ${ }^{1}$ кафедра судової медицини та медичного правознавства, ${ }^{2}$ кафедра внутрішньої медицини та інфекційних хвороб, ${ }^{3}$ КМУ «Бюро судово-медичної експертизи Департаменту охорони здоров’я Чернівецької ОДА»

Резюме. У статті проаналізовано можливість використання методів лазерної поляриметрії для встановлення можливого впливу етилового спирту в організмі померлих на зміну структури полікристалічних плівок цереброспінальної рідини. Доведено ефективність використання методів лазерної поляриметрії (визначення комплексного ступеня взаємної поляризації та автофлюоресценції полікристалічних плівок цереброспінальної рідини). Встановлена статистично достовірна різниця між випадками смерті від серцево-судинної патології при наявності та за відсутності етилового спирту в організмі шляхом визначення величини статистичного моменту 4-го порядку, який характеризує розподіли величини азимута поляризації мікроскопічних зображень лазерно-індукованої флуоресценції. На цій основі досягнута відмінна збалансована точність диференціації наявності етилового спирту в організмі людини $\left(\mathrm{Ac}\left(\mathrm{M}_{4}\right)=94 \%\right)$. Отже, етиловий алкоголь впливає на структуру полікристалічних плівок цереброспинальної рідини, що потрібно враховувати при визначенні давності настання смерті методами лазерної поляриметрії.
\end{abstract}

Ключові слова: судово-медична експертиза, лазерна поляриметрія, давність настання смерті.

ВСТУП. Визначення давності настання смерті (ДНС) є однією з ключових і на сьогодні до кінця не вирішених проблем судово-медичної практики . Це одне з перших і найважливіших питань, що постає перед судово-медичним експертом при огляді трупа на місці події $[1,2]$. На думку одного з провідних світових дослідників цієї проблеми C.Henßge, визначення ДНС - «ахіллесова п’ята» судово-медичної експертизи [3]. Встановлення ДНС $є$ не лише медичною, але і юридичною проблемою, оскільки точне визначення даного показника дозволяє більш якісно і точно проводити розслідування злочинів. Точне встановлення часу настання смерті дозволяє виключити чи підтвердити причетність тих чи інших осіб до скоєння злочину, обмежити чи розширити коло підозрюваних, перевірити правильність показів свідків і підозрюваних $[1,2,4,5]$.

Визначення ДНС ускладнюється також тим, що на посмертні процеси, які відбуваються у тканинах трупа, має вплив значна кількість екзо- та ендогенних чинників, таких як умови навколишнього середовища, причина 
смерті, антропологічні особливості та вік людини, та ін. Останнім часом дослідники почали звертати увагу на вплив алкогольної інтоксикації на швидкість перебігу зажиттєвих процесів та посмертних змін у тканинах людини $[6,7]$.

Дунаєв О. В. [8] помітив, що за наявності алкоголю в крові померлих у випадках смерті травматичного генезу здатність лімфоцитів до розеткоутворення в посмертному періоді зникає раніше, аніж у разі його відсутності та залежить власне від концентрації алкоголю в крові. Зокрема, при концентрації алкоголю в крові 2,1-3,0 \%о впродовж 6-72 після смерті розеткоутворення Т-загальних лімфоцитів збільшується, а при концентрації 3-5 \% зменшується. Розеткоутворення В-лімфоцитів при наявності алкоголю збільшується впродовж 6-24 після смерті, а Т-хелперів та Т-супресорів зменшується впродовж 6-24 та 6-9 годинного посмертного періоду.

Вавилов А. Ю. [9] вказав, що наявність алкоголю в крові померлого, так само як і причина смерті людини, впливають на теплопровідні властивості деяких досліджуваних тканин і органів, відповідним чином змінюючи їx. Зокрема, підвищення загальної теплопровідної властивості головного мозку та печінки відбувається при смерті на тлі крововтрати, отруєння етиловим алкоголем, механічної асфіксії .

Гладких Д. Б. [10] при дослідженні суправітальної зіничної реакції для визначення ДНС виявив, що іiі результати не підлягають оцінці у випадках, коли на момент смерті людина знаходилась у стані алкогольного сп’яніння.

Adinoff В. $з$ колегами [11], вимірюючи рівень аміномасляної кислоти (ГАМК) у ЦСР та в плазмі хворих на алкогольну залежність до початку проведення дезінтоксикаційних маніпуляцій при синдромі відміни у 1-й день і після 21-го дня стаціонарного лікування помітили, що рівень ГАМК плазми та ЦСР корелює з показниками функції печінки та у 1-й день були значно вищими, ніж на 21-й день, причому зміна рівня ГАМК в плазмі суттєво корелювала зі зміною рівня ГАМК в ЦСР.

Для визначення ДНС та зажиттєвості утворення тілесних ушкоджень перспективними $є$ фізичні методи дослідження біологічних тканини (БТ) та біологічних рідин (БР) з використанням лазерних технологій, які включають в себе комплекс фотометричних, поляризаційних і кореляційних методик для вивчення динаміки змін оптичних властивостей біокристалічної структури БТ та БР після настання смерті [12]. Поляризаційні методи дають нову інформацію про морфологічну та оптико-анізотропну структуру БТ, що дає можливість встановити зв'язок між іх фізіологічним станом і поляризаційно-фазовими параметрами зображень їх архітектоніки [13].

Вивчення взаємозв'язків між поляризаційними параметрами, такими як розподіли азимутів та еліптичностей поляризації, параметрів вектора Стокса, показників комплексного ступеня взаємної поляризації (КСВП) зображень зрізів БТ поряд із використанням статистичного аналізу, дозволяє із високою точністю дослідити та інтерпретувати зміни в біологічних об'єктах дослідження [14].

Мета роботи: Вивчити можливий вплив алкоголю та розробити об’єктивні судово-медичні критерії діагностики його впливу на основі аналізу зміни полікристалічної структури плівок ЦСР.

Матеріал і методи дослідження. У роботі використовували методи газово-рідинної хроматографії, поляризаційно-кореляційної мікроскопії (вимірювання КСВП різномасштабних складових мікроскопічного зображення полікристалічних плівок (ПКП) ЦСР); лазерно-індукованої флуоресценції (вимірювання координатних розподілів величини інтенсивності та азимута поляризації мікроскопічних зображень автофлуоресценції ПКП ЦСР); статистичної обробки результатів.

Як об'єкти дослідження у роботі використовувалися 3 групи:

В роботі використовували нативні препарати плівок ЦСР та їі центрифугату. ЦСР була відібрана у 110 трупів обох статей (основна група дослідження) віком від 33-х до 78-и років із попередньо відомим часом настання смерті, що становив від 1 до 26 год - 245 зразків (у деяких трупів ЦСР відбиралася повторно на різних проміжках ДНС) - група 1, та 30 здорових добровольців (група 0) - 30 зразків. Усі добровольці були ознайомлені 3 процедурами дослідження та підписали інформовані згоди щодо участі у дослідженні.

група 2 - посмертні полікристалічні планарні плівки ЦСР, одержані у померлих від серцево судинної патології з наявністю етилового спирту в крові - 30 зразків.

Критеріями виключення були: наявність черепно-мозкової травми, захворювання центральної нервової системи, підозра на інсульт. Забір ЦСР здійснювався методом субокципітальної пункції з великої потиличної цистерни у трупів та при спінальній анестезії при підготовці до оперативних втручань у живих здорових добровольців.

Концентрацію етилового спирту в крові визначали при проведенні судово-медичної експертизи трупів у відділенні судово-медичної токсикології КМУ «Обласне бюро судово-медичної експертизи» департаменту охорони здоров'я Чернівецької ОДА за допомогою газово-рідинної хроматографії на хроматографі «Кристалл-2000М». Умови хроматографічного розділення: хроматограф «Кристалл-2000М», детектор полум'яно-іонізаційний, термостата колонок $75^{\circ} \mathrm{C}$, детектора $-150^{\circ} \mathrm{C}$, індектора $-110^{\circ} \mathrm{C}$, колонка $200(250)$ х 0,3 см, твердий носій Хроматон T-AW, 0,2-0,25, нерухома фаза SE-30, 5\%, газ-носій - азот - 20 мл/хв, повітря 400 мл/хв, водень - 40 мл/хв. Концентрацію етилового спирту в крові виражали в проміле (\%). Кров відбиралася у всіх померли від серцево- 
судинної патології. Залежно від наявності чи відстуності етилового спирту в крові було проведено розподіл на групи досліджуваних.

Плівки ЦСР формувалися в ідентичних умовах шляхом нанесення краплі при кімнатній температурі $\left(\mathrm{t}=22^{\circ} \mathrm{C}\right)$ на оптично однорідне скло.

Вимірювання координатних розподілів (двомірні масиви значень у площині зразків ПКП ЦСР) значень азимута та еліптичності поляризації у точках мікроскопічних зображень виконувалося у розташуванні стандартного стокс-поляриметра (рис. 1), який розроблений науковцями Чернівецького національного університету ім. Юрія Федьковича

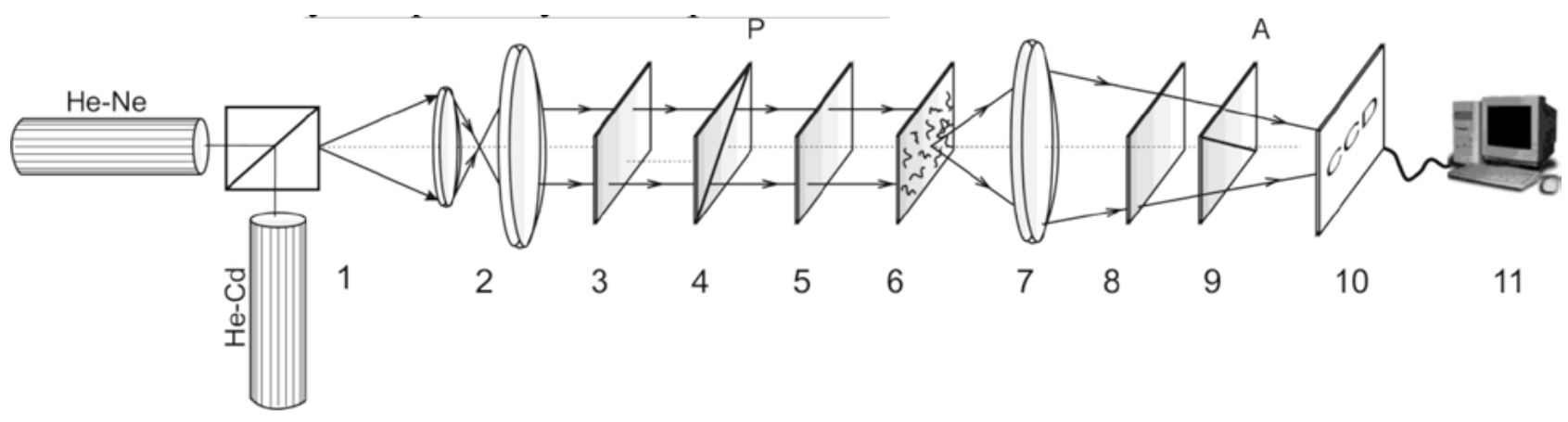

Рис. 1. Оптична схема стокс-поляриметра 3 «двохвильовими» спектральноселективними каналами зондування. Пояснення у тексті.

Режим опромінювання ПКП ЦСР 6 складався $з$ двох каналів:

- поляриметрія - паралельний діаметром 2 мм пучок «червоного» 3 довжиною хвилі 0,63 мкм напівпровідникового лазера 1 ;

- флюорометрія - паралельний діаметром 2 мм пучок «синього» 3 довжиною хвилі 0,405 мкм напівпровідникового лазера 1.

Формування паралельного лазерного пучка здійснювалося за допомогою коліматора 2. Чвертьхвильова пластинки 3 та поляризатор 4 формували заданий стан поляризації зондуючого пучка. Зображення зразків ПКП ЦСР 6 за допомогою поляризаційного мікрооб'єктива 7 проектувалося у світлочутливу площину (кількість пікселів 1280х960) цифрової CCD-камери 10.

Оптичний аналіз мікроскопічних зображень зразків ПКП ЦСР 6 відбувався за допомогою чвертьхвильової пластинки 8 та поляризатора 9.

Головними інформаційними об'єктами для наведеної схеми є сукупність:

- безпосередньо виміряних координатних розподілів величини азимута $(\alpha)$ та еліптичності $(\beta)$ поляризації в точках мікроскопічних зображень - поляризаційні мапи;

- обчислених розподілів поляризаційно-кореляційного параметру - комплексного ступеня взаємної поляризації (КСВП), який характеризує ступень кореляційної узгодженості станів поляризації сусідніх точок мікроскопічного зображення ПКП ЦСР - «поляризаційно-кореляцйні мапи».

На рис. 2 наведена схема модифікованого для досліджень автофлуоресценції біологічних шарів лазерного стокс-поляриметра.

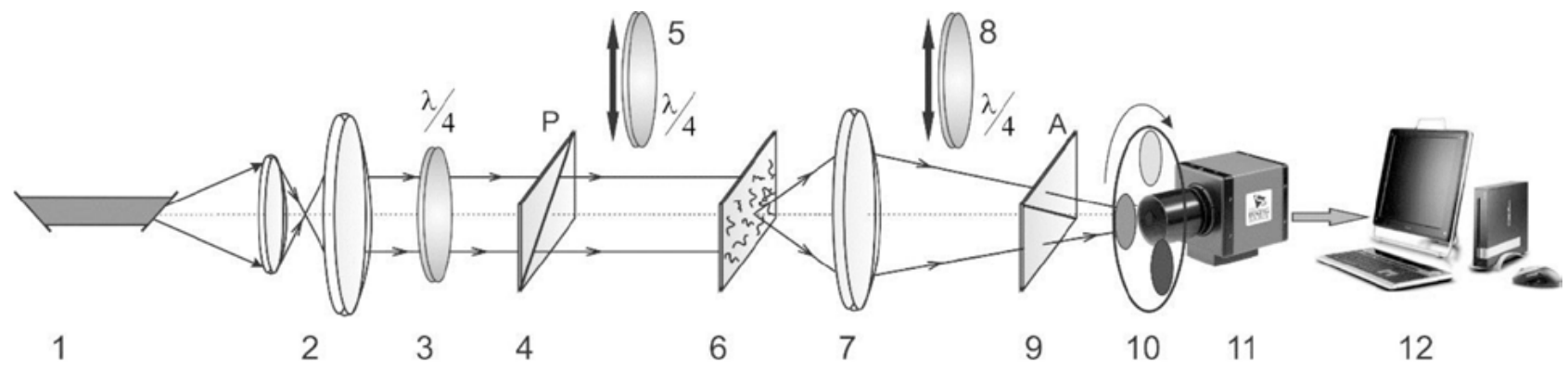

Рис. 2. Оптична схема автофлуоресцентного стокс-поляриметра. Пояснення в тексті 
Для збудження автофлуоресценції ПКП ЦСР (рис. 2) ми використали «синій» напівпровідниковий лазер LSR405ML-LSR-PS-II з довжиною хвилі 0,405 мкм і потужністю 50мВт у розташуванні стандартного стоксполяриметра.

Головними інформаційними об’єктами для наведеної схеми є сукупність:

- безпосередньо виміряних розподілів інтенсивності $I^{\Phi}$ автофлуоресценції ПКП ЦСР;

- азимутів поляризації $\alpha$ лазерно-індукованої флуоресценції полікристалічного шару ЦСР.

Як основний аналітичний інструмент для оцінювання розподілів значень азимута, еліптичності поляризачії, КСВПмікроскопічних зображень, їх високо- та низькочастотних складових, а також інтенсивності та азимутів поляризації флуоресцениії ПКП ЦСР використовувалися статистичні моменти першого, другого, третього і четвертого порядків, які обчислювалися за алгоритмами [13] $i$ характеризують середнє ( $\left.Z_{1}\right)$, дисперсію ( $\left.Z_{2}\right)$, асиметрію $\left(Z_{3}\right)$ та ексиес $\left(Z_{4}\right)$ таких розподілів.

На рис. 3 наведено приклади прямого та просторово-частотного визначення координатної структури КСВП та гістограми розподілів їх значень.
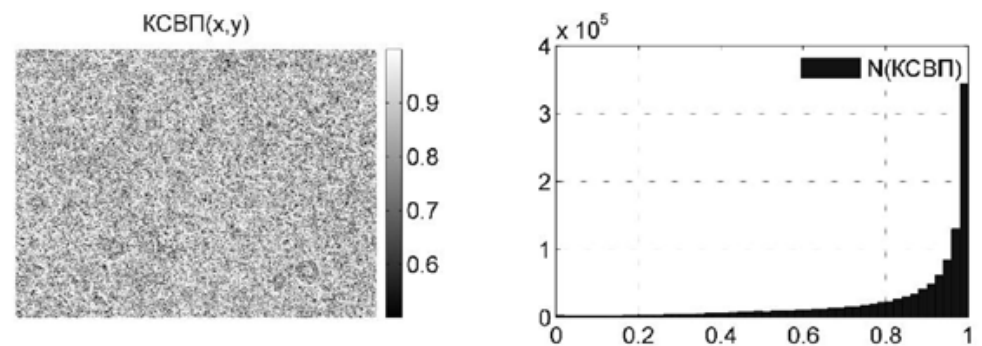

Рис. 3. Двомірна мапа КСВП мікроскопічного зображення ПКП ЦСР (ліва частина) та гістограма розподілу його випадкових значень (права частина)

\section{РЕЗУЛЬТАТИ ТА ЇХ ОБГОВОРЕННЯ:}

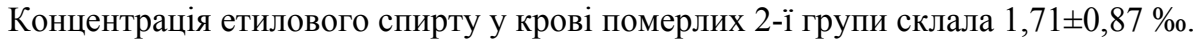

Нами вивчені та наведені систематизовані результати визначення величини статистичних моментів 1-го 4-го порядків, які характеризують розподіли величини КСВП мікроскопічних зображень ПКП ЦСР контрольної донорської та дослідних груп померлих.

Порівняльний аналіз результатів прямого поляризаційно-кореляційного картографування 3 даними поляризаційної мікроскопії зразків ПКП ЦСР всіх трьох груп виявив можливість використання всіх статистичних моментів 1-го - 4-го порядків для диференціації ( $p \prec 0,05)$ зажиттєво (група 0) та посмертно забраної ЦСР (група 1 і група 2).

При цьому гострота піку (ексцес) розподілу значень КСВП мікроскопічних зображень ПКП ЦСР померлих, виявилася чутливою до причини настання смерті - величина довірчого інтервалу $(p \prec 0,05)-3$ задовільною точністю $A_{c}\left(M_{4}\right)=77 \%$

Установлено, що як і у випадку прямого поляризаційного картографування розподілів КСВП сукупності точок поляризаційно-неоднорідних зображень ПКП ЦСР здорових добровольців (група 0) та померлих внаслідок серцевосудинної патології (група 1) та серцево-судинної патології з наявністю етилового спирту в крові (група 2) діагностично актуальним і достовірним ( $p$ 0,05) є статистичнй момент 4-го порядку, обчислення якого забезпечує задовільний рівень збалансованої точності $A c\left(M_{4}\right)=79 \%$ диференціації наявності чи відсутності етилового спирту.

Поляризаційно-кореляційне картографування розподілів КСВП сукупності точок дрібномасштабної складової мікроскопічних зображень ПКП ЦСР дозволило розширити набір судово-медичних критеріїв та підвищити збалансовану точність диференціації зразків ПКП ЦСР, що був забраний у померлих внаслідок серцево-судинної патології з наявністю етилового спирту в крові та без такої.

Виявлено, що величини обчислених статистичних моментів 3-го і 4-го порядків, які характеризують асиметрію та ексцес координатних розподілів значень сукупності точок дрібномасштабної складової мережі ПКП ЦСР померлих, виявилася чутливою до наявності етилового спирту у крові - величина довірчого інтервалу $(p 0,05)$.

Інформжційний аналіз діагностичної сили методу диференціального поляризаційно-кореляційного картографування різномасштабних складових мікроскопічних зображень зразків всіх груп підтвердив даний факт.

Виявлено ряд нових судово-медичних критеріїв задовільного (статистичні моменти 4-го порядку, які характеризують всі типи розподілів величини КСВП $A c\left(M_{4}\right)=77 \%$ - 79\%, а також статистичний момент 3-го порядку, який визначає асиметрію розподілу величини КСВП дрібномасштабної складової $\left.A_{c}\left(M_{3}\right)=83 \%\right)$ та хорошого (ексцес розподілу величини КСВП дрібномасштабної складової $A_{c}\left(M_{4}=86 \%\right.$ ) рівня збалансованої точності методу диференціації наявності етилового спирту в крові шляхом прямого і диференціального поляризаційно- 
кореляційного картографування дрібномасштабної складової КСВП сукупності точок мікроскопічних зображень зразків плівок ЦСР з групи 1 і групи 2. Для інших статистичних моментів збалансована точність залишається на незадовільному рівні.

Наступним кроком стало дослідження можливостей лазерно-індукованої автофлуоресцентної мікроскопії у розроблені судово-медичних критеріїв вивчення впливу етилового спирту на настання смерті від серцевосудинної патології з використанням статистичного аналізу розподілів інтенсивності та азимутів поляризації мікроскопічних зображень флуоресценції ПКП ЦСР у різних спектральних ділянках оптичного випромінювання.

Виявлено наступні судово-медичні критерії хорошого (статистичні моменти 4-го порядку, які характеризують розподіли інтенсивності флуоресценції в «зелено-жовтій» $\mathrm{i}$ «червоній» спектральних ділянках $A_{c}\left(M_{4}\right)=87 \%$ $92 \%$, а також статистичний момент 3-го порядку, який визначає асиметрію розподілу інтенсивності в «червоній» ділянці спектру $A_{c}\left(M_{3}\right)=91 \%$ ) рівня збалансованої точності методу вивчення впливу етилового спирту на настання смерті шляхом спектрально-селективного картографування інтенсивності лазерно-індукованої власної флуоресценції ПКП ЦСР з групи 1 і групи 2.

Для інших статистичних моментів збалансована точність також підвищується до задовільного рівня $A_{c}\left(M_{1,2,3,4}\right)=75 \%-85 \%$.

Продемонстровано підвищення чутливості методу автофлуоресцентної поляриметрії в завданні вивчення впливу етилового спирту на настання смерті у порівнянні з усіма попередньо застосованими методиками прямого і диференціального поляризаційно-кореляційного картографування мікроскопічних зображень. Продемонстрована можливість досягнення відмінного рівня збалансованої точності (статистичний момент 4-го порядку, який характеризує розподіли азимутів флуоресценції в «червоній» спектральні ділянці $A_{c}\left(M_{4}\right)=96 \%$. Для інших статистичних моментів збалансована точність диференціації смерті внаслідок серцево-судинної патології за наявності етилового спирту в крові також підвищується до хорошого рівня $A c\left(M_{1,2,3,4}\right)=75 \%-93 \%$.

Виявлені відмінності в структурі ПКП ЦСР можуть бути пояснені впливом етилового спирту на формування полікристалічної мережі плівки. Імовірно, етиловий спирт, проникаючи через гематоенцефалічний бар'єр, впливає як на кількісний склад середньомолекулярних сполук, на що вказують Витер зі співавт. $[6,15]$, так і на структуру певних білків, зокрема, рецепторів гамма-аміномасляної кислоти, i, таким чином, впливає на третинну і четвертинну структуру білків ЦСР [16] що знаходить своє відображення при аналізі ПКП ЦСР. Одержані нами дані доводять певний вплив етилового спирту на структуру ПКП ЦСР і дозволяють нам рекомендувати різні методологічні підходи щодо визначення ДНС за наявності етилового спирту в крові.

ВИСНОВКИ: нами проаналізовані можливості судово-медичної об'єктивної диференціації визначення впливу етилового спирту на перебіг посмертних процесів при серцево-судинній патології методами поляризаційно-кореляційної та автофлуоресцентної мікроскопії полікристалічних плівок цереброспинальної рідини.

Досліджено взаємозв'язки між розподілами інтенсивності власної флуоресценції полікристалічних плівок цереброспинальної рідини померлих внаслідок серцево-судинної патології з наявністю етилового спирту в крові та без такої і величинами та діапазонами зміни статистичних моментів 1 - 4-го порядків, які характеризують точність диференціації причини настання смерті в «зелено-жовтій» і «червоній» ділянках спектру $A_{c}\left(M_{1,2,3,4}\right)=75 \%$ - 93\% , внаслідок чого ми прийшли до наступних висновків:

1.Проаналізовані можливості судово-медичної об’єктивної диференціації причини настання методами поляризаційно-кореляційної та автофлуоресцентної мікроскопії полікристалічних плівок цереброспинальної рідини померлих внаслідок серцево-судинної патології. Вперше визначено рівні збалансованої точності сукупності методів поляризаційно-кореляційної та спектрально-селективної флуоресцентної мікроскопії.

2.Установлена статистично достовірна різниця для величини ексцесу, який характеризує розподіли комплексного ступеня взаємної поляризації мікроскопічних зображень дрібномасштабної складової полікристалічної мережі плівок цереброспінальної рідини для об'єктивної диференціації присутності етилового спирту в організмі 3 хорошим рівнем збалансованої точності $A_{c}\left(M_{4}\right)=86 \%$.

3.Досліджено взаємозв'язки між розподілами інтенсивності власної флуоресценції полікристалічних плівок цереброспінальної рідини померлих внаслідок серцево-судинної патології за наявності та при відсутності етилового спирту в організмі і величинами та діапазонами зміни статистичних моментів 1 - 4-го порядків, які характеризують такі автофлуоресцентні зображення. Досягнуто хорошого рівня збалансованої точності диференціації наявності етилового спирту в організмі людини в «зелено-жовтій» і «червоній» ділянках спектру $A c\left(M_{1,2,3,4}\right)=75 \%$ $-93 \%$.

4.Встановлена статистично достовірна різниця між випадками смерті від серцево-судинної патології при наявності та за відсутності етилового спирту в організмі шляхом визначення величини статистичного моменту 4-го порядку, який характеризує розподіли величини азимута поляризації мікроскопічних зображень лазерноіндукованої флуоресценції. На цій основі досягнута відмінна збалансована точність диференціації наявності етилового спирту в організмі людини $\left(A c\left(M_{4}\right)=94 \%\right)$. 


\section{Перспектива подальших досліджень}

Етиловий алкоголь впливає на структуру полікристалічних плівок цереброспинальної рідини, що потрібно враховувати при визначенні давності настання смерті методами лазерної поляриметрії. Потребує подальшого вивчення питання визначення давності настання смерті за допомогою методів лазерної поляриметрії у померлих за наявності етилового спирту, у тому числі залежно від його концентрації у крові.

\section{Література}

1. Приходько А.Н. и О.С. Лаврукова К вопросу об использовании биологических объектов для определения давности наступления смерти. Ученые записки Петрозаводского государственного университета. Биологические науки, 2017(2 (163)): p. 85-8.

2. Ольховський B., et al., Визначення тривалості посмертного періоду в судово-медичній експертній практиці: сучасний стан і перспективи. Експериментальна і клінічна медицина, 2016(4): p. 27-33.

3. Henssge C. and B. Madea, Estimation of the time since death. Forensic Sci Int, 2007. 165(2-3): p. 182-4.

4. Гуров О.М., et al., Сучасний алгоритм судово-медичної діагностики давності настання смерті у ранній постмортальний період /Методичні рекомендації. - К. 2017. 34.

5. Бачинський B.T., et al., Сучасні діагностичні можливості судової медицини у вирішенні питання встановлення давності настання смерті. Клінічна та експериментальна патологія, 2017. 14(2).

6. Витер В.И., et al., Оценка концентрации этанола в тканях и биологических жидкостях трупов при отсроченном судебно-химическом исследовании. Судебная экспертиза, 2012(1): p. 121-125.

7. Малков A. and А. Вавилов, Об «оптимизации» коэффициентов, используемых в математических моделях диагностики давности смерти температурным способом. Проблемы экспертизы в медицине, 2011. 11(41-42-1-2).

8. Дунаєв О., Вплив алкоголю на динамікуімунних показників крові померлих від ішемічної хвороби серця (IXC) при встановленні давності настання смерті. Укр. судово-мед. вісн, 2000(1): p. 36-38.

9. Вавилов А.Ю., Судебно-медицинская диагностика давности смерти тепловыми методами. Москва, 2009.

10. Гладких Д.Б., Судово-медична діагностика давності настання смерті за суправітальною реакцією зіниць/ Дис. на здоб. наук. ступ. канд. мед. наук - Харків 2015. 241.

11. Adinoff B., G.L. Kramer, and F. Petty, Levels of gamma-aminobutyric acid in cerebrospinal fluid and plasma during alcohol withdrawal. Psychiatry research, 1995. 59(1): p. 137-144.

12. Бачинський, В., et al., Основні принципи оцінки морфологічного стану біологічних тканин лазерними поляриметричними методами для вирішення завдань судової медицини. Клінічна та експериментальна патологія, 2017(16,№ 1): p. 20-23.

13. Ушенко О., et al., Лазерна поляризаційна морфологія біологічних тканин: статистичний і фрактальний підходи, in Чернівці: Колір-Друк. 2007. p. 314.

14. Ванчуляк О., Можливості використання кореляційного фазового лазерного аналізу для діагностики структурних змін міокарда. Вісник Вінницького національного медичного університету, 2015(19,№ 2): p. 325-328.

15. Витер В. and А. Ермаков, Результаты исследования посмертных изменений уровня среднемолекулярных соединений в спинномозговой жидкости лиц, умерших от болезней системы кровообращения. Проблемы экспертизы в медицине, 2005. 5(18-2).

16. Табакофф Б. and П. Хоффман, Нейробиологические эффекты алкоголя. Вопросы наркологии, 2003(5): p. 27-42.

\section{ИЗУЧЕНИЕ ВЛИЯНИЯ ЭТИЛОВОГО СПИРТА НА ТОЧНОСТЬ ОПРЕДЕЛЕНИЯ ДАВНОСТИ НАСТУПЛЕНИЯ СМЕРТИ ПО ДАННЫМ ЛАЗЕРНОЙ ПОЛЯРИМЕТРИИ ПОЛИКРИСТАЛЛИЧЕСКИХ ПЛЕНОК ЦЕРЕБРОСПИНАЛЬНОЙ ЖИДКОСТИ}

\section{Гараздюк М. С., Бачинский В. Т., Лебединцева И. А., Гараздюк А. И., Андрийчук А. О.}

Резюме. В статье проанализирована возможность использования методов лазерной поляриметрии для возможного воздействия этилового спирта в организме умерших на изменение структуры поликристаллических пленок цереброспинальной жидкости. Доказана эффективность использования методов лазерной поляриметрии (определение комплексного степени взаимного поляризации и автофлюоресценции поликристаллических пленок цереброспинальной жидкости). Установлена статистически достоверная разница между случаями смерти от сердечно-сосудистой патологии при наличии и при отсутствии этилового спирта в организме путем определения величины статистического момента 4-го порядка, который характеризует распределения величины азимута поляризации микроскопических изображений лазерно-индуцированной флуоресценции. Таким образом,, этиловый алкоголь влияет на структуру поликристаллических пленок цереброспинальной жидкости, что нужно учитывать при определении давности наступления смерти методами лазерной поляриметрии.

Ключевые слова: судебно-медицинская экспертиза, лазерная поляриметрия давность наступления смерти. 


\title{
THE EFFECT OF ETHYL ALCOHOL ON ACCURACY OF TIME SINCE DEATH ESTIMATION USING LASER POLIARIMETRIC METHODS OF CEREBROSPINAL LIQUID POLYRISTALLIC FILMS INVESTIGATION
}

\section{Garazdiuk M.S., Bachyns'kyy V.T., Lebedintseva I.O., Garazdiuk O.I., Andriychuk A.O.}

\begin{abstract}
The article analyzes the possibility of using laser polarimetry methods to determine the possible influence of ethyl alcohol in the body of the deceased on the change in the structure of the polycrystalline films of the cerebrospinal fluid. The efficiency of usage laser polarimetry methods (determination of complex degree of mutual polarization and autofluorescence of polycrystalline films of cerebrospinal fluid) have been proved.

Relationships between the distribution of the intensity of the fluorescence of polycrystalline films of the cerebrospinal fluid of the cadavers as a result of cardiovascular pathology in the presence and absence of ethyl alcohol in the organism and the values and ranges of the change of statistical moments of the 1st - 4th orders that characterize such autofluorescence images are investigated. A good level of balanced differentiation of the presence of ethyl alcohol in the human body in the «green-yellow» and «red» sections of the spectrum has been achieved. There is a statistically significant difference between cases of death from cardiovascular disease in the presence and absence of ethyl alcohol in an organism by determining the magnitude of the statistical moment of the 4th order, which characterizes the distributions of the azimuth magnitude of the polarization of microscopic images of laser-induced fluorescence.

On this basis, an excellent balanced accuracy of the differentiation of the presence of ethyl alcohol in the human body (Ac $(\mathrm{M} 4)=94 \%$ ) has been achieved. Consequently, ethyl alcohol affects the structure of polycrystalline films of cerebrospinal fluid, which should be taken into account when time since death estimated using methods of laser polarimetry.
\end{abstract}

Keywords: forensic medicine, laser polarimetry. 